\title{
SIFAT SENSORIS, KIMIA DAN WARNA, RONTO PADA KONSENTRASI GARAM DAN NASI YANG BERBEDA
}

\author{
Nooryantini Soetikno ${ }^{1}$, Susana Ristiarini ${ }^{2}$, Rita Khairina ${ }^{1 \star}$ \\ ${ }^{1}$ Fakultas Perikanan Universitas Lambung Mangkurat: Jalan A. Yani Km 36 Banjarbaru 70713 Kalimantan \\ Selatan, Telepon (0511) 4772124 \\ ${ }^{2}$ Fakultas Bioteknologi Pangan: Universitas Kristen Widya Mandala Jalan. Dinoyo 42 Surabaya 60265 Jawa \\ Timur, Telepon (031) 5678478 \\ *Korespondensi: ritasyaiful@yahoo.co.id \\ Diterima: 26 Oktober 2017/ Disetujui: 21 Maret 2018
}

Cara sitasi: Soetikno N, Ristiarini S, Khairina R. 2018. Sifat sensoris, kimia dan warna, ronto pada konsentrasi garam dan nasi yang berbeda. Jurnal Pengolahan Hasil Perikanan Indonesia. 21(1): 85-91.

\section{Abstrak}

Ronto adalah produk fermentasi udang tradisional yang populer di pesisir pantai Kalimantan Selatan, terbuat dari campuran rebon (Acetes sp.), garam dan nasi yang difermentasi selama 2 minggu pada suhu kamar. Tujuan penelitian ini adalah untuk menentukan pengaruh garam dan nasi terhadap sifat sensoris, kimia dan warna ronto. Penelitian dirancang dengan rancangan acak lengkap faktorial (RALF), faktor pertama adalah konsentrasi garam (10, 11 dan 12\%), faktor kedua adalah konsentrasi nasi (20 dan 30\%). Hasil penelitian menunjukkan bahwa pemberian garam dan nasi berpengaruh terhadap kualitas sensoris, kimia, dan warna ronto. Perlakuan terbaik adalah penambahan garam $12 \%$ dan nasi $20 \%$ dengan nilai sensoris warna 4,93, aroma 4,97, tekstur 3,97 dan kenampakan 4,57. Nilai pH 5,2, total asam 25,30 mg/g, TVB 94,14 mg N/100 gram dan Aw 0,89, warna ronto adalah $\mathrm{L}^{\star}=44,36, \mathrm{a}^{\star}=11,89$, dan $\mathrm{b}^{\star}=8,45$.

Kata kunci: Acetes sp., kimiawi, ronto, sensoris, warna

\section{The Sensory, Chemical and Color Properties of Ronto on the Differences Concentrations Salt and Rice}

\begin{abstract}
Ronto is a popular traditional fermented product in South Kalimantan, made from mixture of shrimps (Acetes sp.), salt and rice which incubation for 2 week at room temperature. The Objective of this research is to find out effect of additional salt and rice to sensory, chemical and color of ronto The Research has been designed by complete randomized design factorial, the treatment used with salt concentrations is $10 \%$, $11 \%, 12 \%$, and rice $20 \%$ and $30 \%$ respectively. The result of research shows that additional salt and rice are affected to sensory, chemical and color of ronto. The best treatment is G12N20, with additional salt $12 \%$ and rice $20 \%$ (G12N2) with sensory, color, flavor, texture values are 5.2, 25.29 mg/g, $94.14 \mathrm{mg} \mathrm{N} / 100$ gram, 0.90 . The acidity, $\mathrm{pH}$, total volatile bases and water activity value are $25.30 \mathrm{mg} / \mathrm{g}, 5.24,94.40$ and 0.89 , respectively. The color value of ronto are $\mathrm{L}^{\star}=44.36, \mathrm{a}^{\star}=11.89$, dan 8.45 .
\end{abstract}

Keyword: Acetes sp., chemical, color, ronto, sensory

\section{PENDAHULUAN}

Produk olahan berbahan rebon yang banyak ditemukan dipesisir pantai Kalimantan Selatan adalah rebon kering (udang papai), terasi (acan) dan ronto (Syahrin et al. 2016). Rebon kering menempati urutan pertama dari ketiga produk olahan tersebut, diikuti oleh terasi dan ronto. Rebon kering diolah nelayan apabila pendaratan tangkapan berlangsung pagi atau siang hari, tetapi apabila pendaratan rebon terjadi pada sore hari maka nelayan akan melakukan pengolahan rebon menjadi terasi atau ronto. Ronto terbuat dari campuran rebon, garam dan nasi dengan perbandingan $7: 1: 2$, difermentasi secara anaerob selama 2 minggu (Khairina et al. 2013; Khairina et al. 2016 ${ }^{\mathrm{a}}$, Khairina et al. 2016 ${ }^{\mathrm{b}}$ ).

Khairina et al. (2017) melaporkan bahwa deskripsi kualitas sensoris (aroma, warna, rasa dan tekstur) ronto setelah fermentasi 12 hari adalah beraroma asam menyengat, asin garam tercium kuat dan aroma udang fermentasi, 
berwarna merah muda terang, berasa asam dengan flavor gurih udang fermentasi yang kuat. Bertekstur seperti bubur dengan suspensi hancuran nasi dan daging udang. Nilai warna, keasaman dan nilai total volatil basis (TVB-N) ronto adalah $\mathrm{L}=53,42 ; \mathrm{a}=10,61 ; \mathrm{b}=15,34 ; \mathrm{o}$ Hue $=49,57$; dan Chroma $=19,16$. Total asam, $\mathrm{pH}$ dan nilai TVB-N adalah $+18 \mathrm{mg} / \mathrm{g}, 5,0$, dan $150 \mathrm{mg} \mathrm{N} / 100 \mathrm{~g}$ sampel.

Pengolah ronto menggunakan jenis takaran yang berbeda-beda dalam menentukan perbandingan antara udang:garam:nasi, sehingga kualitas produk antar pengolah juga berbeda-beda (Khairina et al. 2013). Pengolahan ronto berskala kecil $(<5 \mathrm{~kg})$ menggunakan mangkok kecil sebagai takaran, sedangkan pengolahan berkapasitas lebih dari $10 \mathrm{~kg}$ takaran yang dipergunakan adalah ember atau kaleng bervolume 1-3 kg, perbedaan takaran yang digunakan akan mempengaruhi perbandingan garam dan nasi yang ditambakan sehingga akan berpengaruh terhadap kualitas produk yang dihasilkan.

Penggunaan garam $10 \%$ sudah mampu mengawetkan ikan (Steinkraust 2000), sedangkan penambahan karbohidrat dalam pengolahan ikan membantu pertumbuhan bakteri asam laktat (Rhee et al. 2010; Adams 2011). Persentasi garam dan nasi yang digunakan dalam pengolah ronto dengan perbandingan rebon:garam:nasi $=7: 1: 2$ adalah sekitar $11,47 \%$ garam dan $19,67 \%$ nasi (Khairina et al. 2016 $)$. Berdasarkan data tersebut maka penelitian ini mencoba memformulasikan penggunaan garam dan nasi menjadi persentase sehingga hasil penelitian ini diharapkan dapat merekomendasikan jumlah garam dan nasi yang terbaik pada pengolahan ronto. Tujuan penelitian ini adalah untuk menentukan pengaruh pemberian garam dan nasi terhadap sifat sensoris, kimia dan warna ronto.

\section{BAHAN DAN METODE Bahan dan Alat}

Udang rebon (Acetes sp.) diperoleh dari nelayan penangkap di Desa Muara Kintap, Kecamatan Kintap, Kabupaten Tanah Laut, Propinsi Kalimantan Selatan. Garam yang digunakan dibeli di pasar Muara Kintap. Nasi yang digunakan adalah beras IR-32. Peralatan yang digunakan adalah keranjang tempat mencuci udang rebon, box, rice-cooker (Miyako-MCM 508), alat-alat gelas, blender (miyako GL 105 GS), spectrofotometer (Shimadzu UV 1650 PC), sentrifuse, inkubator, chromameter-Minolta (CR-310) dan viskometer (Brookfield DV-11 ${ }^{+}$Pro).

\section{Metode Penelitian \\ Pembuatan Ronto}

Ronto diolah mengacu pada metode Khairina et al. (2016) dan Khairina (2017) yang dimodifikasi. Rebon sebanyak $1 \mathrm{~kg}$ dicampur dengan garam sesuai perlakuan, kemudian didiamkan selama dua jam, selanjutnya ditambahkan nasi sesuai perlakuan dan diaduk hingga tercampur rata. Campuran disimpan dalam botol bervolume $350 \mathrm{~mL}$ untuk difermentasikan selama 2 minggu.

Parameter pengamatan pada penelitian ini mengacu pada Khairina (2017). Fermentasi berlangsung 12 hari, setelah itu dilakukan analisis sensoris (warna, aroma, rasa, kenampakan), warna, keasaman (total asam dan $\mathrm{pH}$ ) serta Total Volatil Bases (TVB-N).

\section{Pengamatan Sensoris}

Sifat sensoris ronto diamati oleh 10 orang panelis dengan uji kesukaan berdasar skala hedonik mengacu pada metode Setyaningsih et al. (2010). Skala penilaian mulai dari 5 sangat suka sampai dengan 1 tidak suka. Panelis melakukan penilaian menggunakan score sheet dengan skala nilai sebagai berikut, 5 (sangat suka), 4 (suka), 3 (kurang suka), 2 (sedikit suka) dan 1 (tidak suka).

\section{Pengamatan Warna}

Warna ronto diukur dengan Chromameter-Minolta CR-400, mengacu pada Khairina (2017). Sampel dimasukkan ke dalam tabung silinder berdiameter $3 \mathrm{~cm}$ dan tinggi $1 \mathrm{~cm}$, kemudian chromameter difokuskan ke arah sampel dan pengukuran dilakukan sebanyak 5 kali pada berbagai sudut pengamatan. Rata-rata lima kali pengamatan diambil sebagai data. Hasil pengukuran dinyatakan dengan nilai $L^{\star}$ (ligthness), 
$\mathrm{a}^{\star}$ (redness/greenness) dan $\quad \mathrm{b}^{\star}$ (yellowness/ blueness). Perhitungan data yang diperoleh menggunakan rumus yang mengacu pada Pongsetkul et al. (2014). Perbedaan warna $\left(\Delta \mathrm{E}^{\star}\right)$ dan perbedaan chroma $\left(\Delta \mathrm{C}^{\star}\right)$ dihitung dengan rumus sebagai berikut:

$$
\Delta E^{\star}=\sqrt{\left(\Delta L^{\star}\right)^{2}+\left(\Delta a^{\star}\right)^{2}+\left(\Delta b^{\star}\right)^{2}}
$$

$\Delta \mathrm{L}^{*}, \quad \Delta \mathrm{a}^{*}$ dan $\Delta \mathrm{b}^{*}$ adalah differensial antara parameter warna sampel dengan standar warna putih yaitu $L^{*}=93,55, a^{*}=-0,84, b^{*}=0,37, \Delta C^{*}=C_{\text {sampel }}^{*} C_{\text {standard }}^{*}$ sedangkan $C^{*}=\sqrt{\left(a^{*}\right)^{2}+\left(b^{*}\right)^{2}}$

\section{Analisis Kimia}

Sampel sebanyak 200 g diblender pada kecepatan maksimum selama 5 menit. Hancuran sampel diambil untuk pengukuran $\mathrm{pH}$, total asam, total volatile base dan aktivitas air (Aw). Pengukuran $\mathrm{pH}$ menggunakan $25 \mathrm{mg}$ hancuran sampel dicampur dengan akuades hingga homogen.

Titrasi asam diukur menggunakan 0,1 $\mathrm{N} \mathrm{NaOH}$ dengan indikator phenolphthalein (AOAC 1995). Pengujian total volatil basis dilakukan dengan metode Conway microdiffusion. Nilai total volatile basis dinyatakan sebagai mg N/100 g sampel (Connel 1990). Pengukuran aktivitas air (Aw) menggunakan Aw meter dengan cara memasukkan hancuran sampel dalam tabung silinder berdiameter 3 $\mathrm{cm}$ dan tinggi $1 \mathrm{~cm}$ sampai penuh kemudian diukur dengan Aw-meter sampai alat menunjukan nilai konstan.

\section{Analisis Data}

Penelitian ini dirancang dengan pola rancangan acak lengkap factorial (RALF). Rebon yang digunakan untuk setiap perlakuan sebanyak $1 \mathrm{Kg}$. Perlakuan yang diterapkan adalah konsentrasi garam dan nasi, dan diulang sebanyak 3 kali. Rancangan penelitian didesain sebagai berikut:

\section{HASIL DAN PEMBAHASAN}

Ronto yang dihasilkan setelah fermentasi 12 hari berwarna merah muda, beraroma udang fermentasi dengan bau asam yang menonjol, tekstur seperti bubur dengan partikel hancuran nasi dan rebon. Khairina et al. (2017) melaporkan bahwa rasa ronto adalah campuran rasa asam, asin dan gurih dengan flavor udang fermentasi yang kuat. Ronto hasil fermentasi 12 hari dapat dilihat pada Gambar 1. Pemberian garam dan nasi yang berbeda memperlihatkan adanya perbedaan sifat sensoris, warna, sifat kimia, dan sifat mikrobiologis antar perlakuan.

\section{Sifat Sensoris}

Uji sensoris menunjukan bahwa perlakuan G11N20, G10N30, dan G11N30 tidak berbeda nyata dengan perlakuan kontrol, tetapi pemberian garam $10 \%$ dan nasi $30 \%$ (G10N30) memperlihatkan nilai kesukaan tertinggi. Pemberian garam 10\% dan $11 \%$ terlihat tidak berbeda terhadap penerimaan warna ronto. Nilai sensoris aroma, pada semua perlakuan berbeda nyata dengan kontrol. Terlihat bahwa perlakuan G10N20, G11N20, dan G11N30 memiliki nilai tertinggi dengan kriteria sangat suka (Tabel 1).

Khairina et al. (2016) dan Khairina et al. (2017) melaporkan bahwa jumlah garam yang digunakan pada pengolahan ronto sekitar $12,67 \%$, merupakan konversi dari hasil takaran dengan perbandingan udang:garam: nasi 7:1:2. Berbagai produk olahan hasil perikanan selalu menggunakan garam sebagai bahan pengawet. Pemberian garam 10\% sudah mampu menghambat pertumbuhan bakteri pembusuk dan patogen (Steinkraust, 2000). Jumlah garam yang diberikan selain sebagai bahan pengawet berpengaruh terhadap kualitas sensoris ronto terutama rasa. Garam tinggi menjadi pembatas bagi konsumen karena

\begin{tabular}{|c|c|c|c|c|}
\hline \multirow{2}{*}{$\begin{array}{l}\text { Treatment of rice } \\
\text { concentration }(\mathrm{N})\end{array}$} & \multicolumn{4}{|c|}{ Salt concentration $(G)$} \\
\hline & $\mathrm{G} 10 \% \mathrm{~b} / \mathrm{b}$ & $\mathrm{G} 11 \% \mathrm{~b} / \mathrm{b}$ & $\mathrm{G} 12 \% \mathrm{~b} / \mathrm{b}$ & Kontrol \\
\hline $\mathrm{N} 1(20 \% \mathrm{~b} / \mathrm{b})$ & G10N20 & G11N20 & G12N20 & $\mathrm{K} 1(7: 1: 2)$ \\
\hline $\mathrm{N} 2(30 \% \mathrm{~b} / \mathrm{b})$ & G10N30 & G11N30 & G12N30 & \\
\hline
\end{tabular}




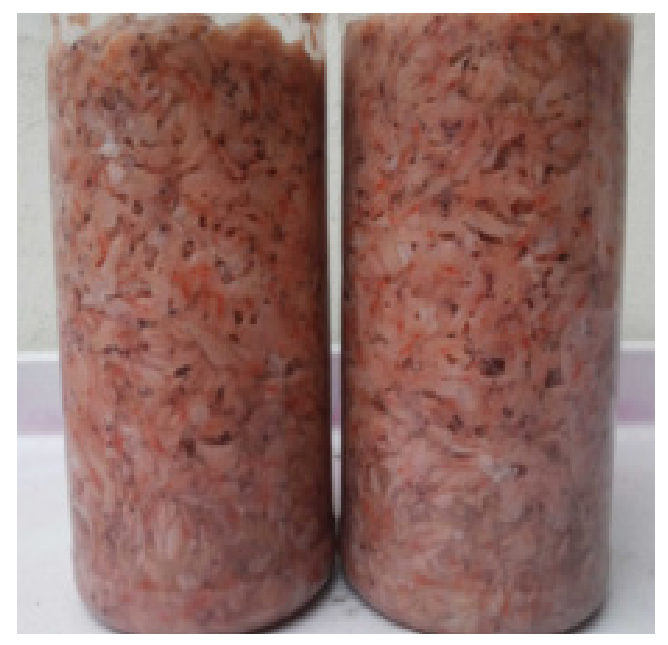

Gambar 1 Ronto pada fermentasi 12 hari (Figure 1 Ronto on 12 day fermentation)

rasa yang sangat asin, tetapi produk bergaram tinggi cenderung memiliki daya awet yang lebih baik, oleh sebab itu, menentukan jumlah garam yang optimum bagi proses fermentasi ronto perlu diketahui agar diperoleh ronto yang awet dengan sifat sensoris yang diterima oleh konsumen. Hasil uji sensoris terhadap ronto pada berbagai konsentrasi garam dan nasi dapat dilihat pada Tabel 1.

\section{Warna Ronto}

Warna ronto hasil penelitian ini berada pada kisaran nilai $\mathrm{L}^{\star} 44,36-47,01, \mathrm{a}^{\star} 11,49$ 12,49 , dan nilai $\mathrm{b}^{*} 8,45-11,32$, dibandingkan dengan hasil penelitian Khairina et al. (2016) dan Khairina et al. (2017) warna ronto hasil penelitian ini lebih rendah. Deskripsi warna ronto setelah fermentasi adalah merah muda terang dengan nilai $L^{*} 53,42, a^{*} 10,61, b^{*}$ 15,34 , Hue 49,57 dan chroma 19,16 . Warna ronto dapat dilihat pada Gambar 2.

Perubahan warna ronto selama fermentasi berhubungan dengan kandungan karoten dan axtasantin yang ada pada kulit dan daging udang rebon. Ikatan protein dan senyawa pengikat kulit udang terurai selama fermentasi menyebabkan ikatan karoten dan astaxanthin terlepas sehingga terjadi perubahan warna, selama fermentasi protein udang mengalami proteolisis oleh kelompok bakteri protease indigenous yang menguraikan protein menjadi peptida rantai pendek dan

Tabel 1 Pengaruh konsentrasi garam dan nasi yang berbeda terhadap kualitas sensoris ronto

(Table 1 Effect of different concentrations of salt and rice on the sensory quality of ronto)

\begin{tabular}{ccccc}
\hline Treatment $(w / w)$ & Color & Flavor & Texsture & Appearance \\
\hline Salt 10\% and rice 20\% (G10N20) & $4.67 \pm 0.06^{\mathrm{b}}$ & $4.93 \pm 0.06^{\mathrm{a}}$ & $3.53 \pm 0.21^{\mathrm{c}}$ & $3.50 \pm 0.20^{\mathrm{c}}$ \\
Salt $11 \%$ and rice 20\% (G11N20) & $4.93 \pm 0.06^{\mathrm{a}}$ & $4.97 \pm 0.06^{\mathrm{a}}$ & $3.97 \pm 0.06^{\mathrm{b}}$ & $4.57 \pm 0.06^{\mathrm{a}}$ \\
Salt $12 \%$ and rice $20 \%(G 12 N 20)$ & $4.43 \pm 0.06^{\mathrm{c}}$ & $4.70 \pm 0.10^{\mathrm{b}}$ & $3.47 \pm 0.12^{\mathrm{c}}$ & $3.77 \pm 0.29^{\mathrm{c}}$ \\
Salt 10\% and rice 30\% (G10N30) & $4.97 \pm 0.06^{\mathrm{a}}$ & $4.60 \pm 0.00^{\mathrm{b}}$ & $3.97 \pm 0.15^{\mathrm{b}}$ & $4.30 \pm 0.10^{\mathrm{ab}}$ \\
Salt 11\% and rice 30\% (G11N30) & $4.93 \pm 0.06^{\mathrm{a}}$ & $4.93 \pm 0.06^{\mathrm{a}}$ & $4.10 \pm 0.10^{\mathrm{b}}$ & $4.53 \pm 0.06^{\mathrm{a}}$ \\
Salt 12\% and rice 30\% (G12N30) & $3.40 \pm 0.10^{\mathrm{d}}$ & $4.20 \pm 0.17^{\mathrm{c}}$ & $2.83 \pm 0.15^{\mathrm{d}}$ & $2.70 \pm 0.10^{\mathrm{d}}$ \\
Control & $4.93 \pm 0.06^{\mathrm{a}}$ & $3.90 \pm 0.10^{\mathrm{d}}$ & $4.40 \pm 0.10^{\mathrm{a}}$ & $4.07 \pm 0.12^{\mathrm{b}}$ \\
\hline
\end{tabular}

Information: 5 = very like, 4 = like, 3 = less like, $2=$ little likes, $1=$ dislike 


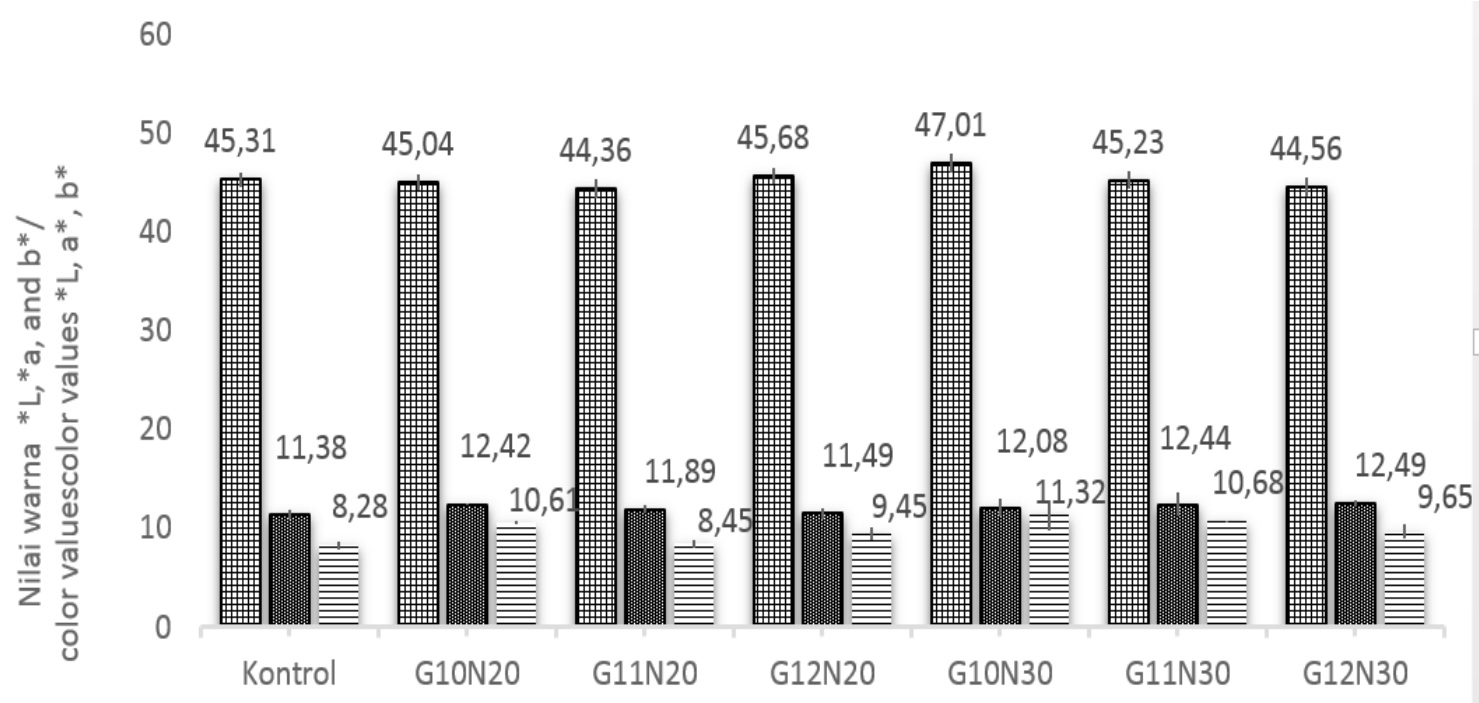

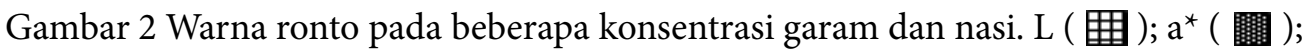
${ }^{*} \mathrm{~b}($ 目 $)$

(Figure 2 The color of ronto at different concentrations of salt and rice. $L$ ( 曲); $a^{*}$ (聞); ${ }^{*} b($ 目)).

amino bebas (Chaijan dan Panpipat 2012). Senyawa tersebut membentuk flavor dan rasa spesifik pada produk udang fermentasi (Faithong et al. 2010). Berbagai reaksi biokimia terjadi selama fermentasi udang dan akibat dari reaksi tersebut terjadi pengembangan warna, aroma, rasa dan tekstur produk fermentasi udang. Proteolisis dan hidrolisis menyebabkan terjadi pelepasan astaxantin dari ikatan protein sehingga menghasilkan perubahan warna dari merah muda (reddish-pink) menjadi warna oranye. Ketika udang rebon masih segar warnanya adalah abu-abu ke arah putih pucat dan selanjutnya warna perlahan-lahan akan berubah menjadi merah muda pucat dengan peningkatan intensitas hingga menjadi merah muda terang. Menurut Arjuan (2008) dan Chaijan dan Panpipat (2012) bahwa perubahan warna berupa nilai $\mathrm{L}^{*}, \mathrm{a}^{*}$, dan $\mathrm{b}^{*}$ pada produk udang fermentasi dipengaruhi oleh kandungan karoten dan astaxantin dalam kulit udang. Astaxanthin disebut juga sebagai xantophyl merah dengan rumus kimia (3,3'-dihydroxyi,i-carotene-4,4'-dione) yang berperan pembentukan warna spesifik kelompok udang-udangan (Rodriquez et al. 2010).

\section{Total Asam dan Nilai pH}

Perbedaan

konsentrasi

garam berpengaruh terhadap total asam dan nilai $\mathrm{pH}$ ronto yang dihasilkan (Tabel 2). Ronto dengan pemberian garam $10 \%$ dan nasi 30\% (G10N30) memiliki $\mathrm{pH}$ terendah dan pemberian garam $10 \%$ dan nasi $20 \%$ (G10N20) memperlihatkan total asam yang tertinggi. Hasil penelitian menunjukkan bahwa rendahnya $\mathrm{pH}$ tidak berhubungan langsung dengan tingginya total asam.

Produk fermentasi udang misalnya kungsom, rusip, cincalok, cincaluk dan balaobalao mengalami penurunan $\mathrm{pH}$ mencapai $4,5-5,0$, penurunan $\mathrm{pH}$ merupakan indikator berhasilnya proses fermentasi (Khairina 2017). Kung-som memiliki nilai pH berkisar 4,5-5,5 dan nilai asam laktat $0,87-29,9 \mathrm{mg} / \mathrm{g}$, rusip dengan $\mathrm{pH} 5,98$ dan kandungan asam laktat $31,2 \mathrm{mg} / \mathrm{g}$, shik-kae dengan $\mathrm{pH} 4,8$, kandungan asam laktat $25 \mathrm{mg} / \mathrm{g}$ (Fernandez 2009; Koesoemawardhani et al. (2013); Rhee et al. (2011))

Nilai $\mathrm{pH}$ pada umumnya akan menurun cepat apabila bahan bakunya adalah karbohidrat yang mudah difermentasi. Beras adalah sumber karbohidrat yang paling umum digunakan baik dalam bentuk nasi atau 
Tabel 2 Karakteristik kimia dan warna ronto

(Table 2 Chemical characteristics and ronto color)

\begin{tabular}{ccccc}
\hline Treatment $(w / w)$ & $\begin{array}{c}\text { Total acid } \\
\text { value }\end{array}$ & $\begin{array}{c}p H \text { (potential } \\
\text { of hydrogen }\end{array}$ & $\begin{array}{c}\text { Total volatile } \\
\text { bases }\end{array}$ & $\begin{array}{c}\text { Water activity } \\
(\mathrm{Aw})\end{array}$ \\
\hline Salt 10\% and rice $20 \%(\mathrm{G} 10 \mathrm{~N} 20)$ & $30.758 \pm 0.41$ & $6.59 \pm 0.09$ & $116.27 \pm 4.65$ & $0.898 \pm 0.01$ \\
Salt 11\% and rice $20 \%(\mathrm{G} 11 \mathrm{~N} 20)$ & $25.588 \pm 0.64$ & $6.32 \pm 0.04$ & $122.33 \pm 10.19$ & $0.898 \pm 0.01$ \\
Salt $12 \%$ and rice $20 \%(\mathrm{G} 12 \mathrm{~N} 20)$ & $25.297 \pm 0.83$ & $5.24 \pm 0.02$ & $94.14 \pm 16.55$ & $0.892 \pm 0.00$ \\
Salt 10\% and rice 30\% (G10N30) & $25.173 \pm 0.80$ & $4.89 \pm 0.09$ & $109.74 \pm 7.96$ & $0.904 \pm 0.01$ \\
Salt 11\% and rice 30\% (G11N30) & $23.893 \pm 0.66$ & $5.01 \pm 0.02$ & $119.88 \pm 4.83$ & $0.899 \pm 0.00$ \\
Salt 12\% and rice 30\% (G12N30) & $25.085 \pm 0.51$ & $5.08 \pm 0.01$ & $110.35 \pm 0.60$ & $0.899 \pm 0.00$ \\
Control & $24.392 \pm 0.61$ & $5.30 \pm 0.12$ & $156.91 \pm 2.74$ & $0.869 \pm 0.01$ \\
\hline
\end{tabular}

beras sangrai sehingga memberi kesempatan proses sakarifikasi oleh bakteri amylolytic dan bakteri lainnya (Fernandez 2009). Total asam yang tinggi berpengaruh terhadap rasa ronto, sehingga secara sensoris akan kurang disukai. Karakteristik ronto selama 12 hari waktu fermentasi dapat dilihat pada Tabel 2.

\section{Nilai Total Volatile Basis (TVB-N) dan Aktivitas Air (Aw)}

Nilai total volatil basis adalah akumulasi dari trimethylamine, dimethylamine dan amoniak. Connel et al. (1990) menyatakan bahwa batas nilai total volatil basis untuk tingkat kebusukan produk olahan hasil perikanan yaitu $200 \mathrm{mg} \mathrm{N} / 100 \mathrm{~g}$ sampel. Hasil uji anova menunjukkan bahwa nilai TVB-N ronto dengan pemberian garam $12 \%$ dengan nasi $20 \%$ tidak berbeda dengan pemberian garam $10 \%$ dan nasi $30 \%$ atau garam $12 \%$ dengan nasi 30\% (Tabel 2)

Penguraian protein berhubungan dengan pembentukan aroma ronto selama fermentasi yang ditandai dengan nilai Total Volatil Basis (TVB-N). Khairina et al. (2017) melaporkan bahwa terjadi peningkatan nilai total volatil basis ronto selama fermentasi 12 hari yaitu $150 \mathrm{mg} \mathrm{N} / 100 \mathrm{~g}$ sampel, nilai total volatil basis sejalan dengan penelitian sik-khae (Rhee et al. 2011).

Perbedaan garam dan nasi yang diberikan berpengaruh terhadap nilai Aw ronto, hasil analisis keragaman menunjukkan bahwa terdapat beda nyata antar perlakuan. Nilai Aw paling rendah ditunjukkan oleh perlakuan kontrol. Proses fermentasi ronto menyebabkan penurunan aktivitas air dan terjadi secara signifikan mulai fermentasi hari ke-4 dan pada hari ke-12 mencapai 0,83 (Khairina et al. 2016). Nilai $A_{w}$ turun dipengaruhi oleh garam dan kadar air produk selama fermentasi (Abbas et al.2009). Aktivitas air dalam bahan makanan digunakan oleh para profesional dalam upaya pengembangan produk, pengendalian mutu dan keamanan pangan, sehingga menjadi kriteria penting untuk evaluasi dan pengendalian keamanan dan kualitas pangan.

Adam dan Nouts (2001) menyatakan bahwa pertumbuhan dan metabolisme mikrobia yang berperan selama fermentasi dipengaruhi oleh kadar air dan aktivitas air dalam bahan. Nilai Aw optimum untuk bakteri adalah 0,8 - 0,9, yeast 0,7-0,8, dan kapang $<0,7$, oleh sebab itu jika nilai $A_{w}$ lebih rendah dari nilai tersebut sistem metabolisme dan pertumbuhan mikrobia pembusuk dan patogen akan terganggu karena tidak mampu tumbuh pada Aw rendah. Kondisi ini sangat menguntungkan dalam proses pengawetan makanan termasuk makanan fermentasi di antaranya ronto.

\section{KESIMPULAN}

Perbedaan konsentrasi garam dan nasi berpengaruh terhadap sifat sensoris, kimia dan warna ronto yang dihasilkan. Perlakuan terbaik adalah yaitu pemberian garam $12 \%$ dan nasi $20 \%$ dengan nilai sensoris warna 4,93 , aroma 4,97, tekstur 3,97 dan kenampakan 
4,57. Nilai pH 5,2, total asam $25,29 \mathrm{mg} / \mathrm{g}$, TVB 94,14 mg N/100 gram, Aw 0,90. Nilai uji chromameter warna ronto adalah $\mathrm{L}^{\star}=44,36$, $\mathrm{a}^{*}=11,89$, dan 8,45 .

\section{Ucapan Terima Kasih}

Terima kasih disampaikan kepada Dirjen Pendidikan Tinggi yang telah memberikan dukungan dana melalui Penelitian Hibah Terapan Tahun 2017.

\section{DAFTAR PUSTAKA}

Abbas KA, Saleh AM, Mohammed A, Lasekan O. 2009. The relationship between water activity and fish spoilage during cold storage: A review. Journal Food, Agriculture and Environment. 7(374): 8690.

Adams M. 2009. Fermented Fish. in Microbiology Handbook Fish and Seafood. Surrey-(UK): Leatherhead Food International.

Adams MR, Nout MJR. 2001. Fermentation and Foof Safety. Maryland (AS): An Aspen Publication. Gaithersburg.

[AOAC] Association of Official Analytical and Chemistry. 1995. Official Methods of Analysis Association of Official Analytical Chemist. Washington (US): Association of Official Analytical and Chemistry.

Connel JJ. (1990). Control of Fish Quality, 3rd Edition. Oxford (UK) Fishing New Books.

Chaijan M, Panpipat W. 2012. Darkening prevention of fermented shrimp paste by pre-soaking whole shrimp with pyrophosphate. Asian Jurnal of Food and Agro-Industry. 5(02): 163-171.

Faithong N, Benjakul S. Phatcharat S, Binsan W. 2010. Chemical composition and antioksidative activity of Thai traditional fermented shrimp and krill products. Food Chemistry. 119: 133-140.

Fernandez R. 2009. Microbiology Handbook Fish and Seafood. Leatherhead Food International Ltd ISBN: 978-1-90522476-0. http://www.rsc.org. Regstered Charity.

Koesoemawardhani D, Rizal S, Tauhid M. 2013. Perubahan sifat mikrobiologi dan kimiawi rusip selama fermentasi.
Agritech. 33(3): 265-272.

Khairina R, Fitrial Y, Satria H, Rahmi N. 2013. Profil ronto produk fermentasi udang tradisional di Kalimantan Selatan. Prosiding seminar nasional. Masyarakat Pengolahan Hasil Perikanan Indonesia (MPHPI). 2013: 153-159.

Khairina R, Fitrial F, Satria H, Rahmi N. 2016a. Physical, Chemical, Microbiological Properties of Ronto a Traditional Fermented Shrimp from South Borneo, Indonesia. Aquatic Proceedia International Symposium on Aquatic Products Processing and Health ISAPPROSH. 2016: 214-220.

Khairina R, Cahyanto MN, Utami T, Rahardjo S. 2016 . Karakteristik fisikawi, kimiawi, dan mikrobiologis ronto selama penyimpanan. Jurnal Pengolahan Hasil Perikanan Indonesia. 19(3): 348-355.

Khairina R, Utami T, Raharjo S, Cahyanto MN. 2017. Changes in sensory, physicochemical, and microbiological properties of ronto during fermentation. Pakistan Journal of Nutrition. 16: 629-637.

Khairina R. 2017. Perubahan Sifat Sensoris Fisik Kimia dan Mikrobiologis Selama Fermentasi dan Penyimpanan Ronto. [Disertasi]. Yogyakarta (ID): Universitas Gadjah Mada.

Pongsetkul J, Benjakul S, Sampavapol P, Osaka K, Faithong N. 2014. Chemical composition and physical properties of salted shrimp paste (Kapi) produced in Thailand. International Aquatic Research. 6: 155-166.

Rhee SJ, Lee JE, Lee CH. 2011. Importance of lactic acid bacteria in Asian fermented foods. Proceeding. From $10^{\text {th }}$ Symposium on Lactic Acid Bacterium. Egmond aan Zee, the Netherlands. 28 August - 1 September 2011.

Syahrin A, Mahydin I, Mahreda ES. 2016. Prospek Usaha Pengolahan Udang Rebon Skala Rumah Tangga Di Desa Muara Kintap Kecamatan Kintap Kabupaten Tanah Laut Provinsi Kalimantan Selatan. Enviro Scientae 12(3): 149-159. 